\title{
Review
}

\section{Victory: The triumph and tragedy of just war}

\author{
Cian O'Driscoll \\ Oxford University Press, Oxford, 2020. ix+172 pp. \\ ISBN: 978-0-19-883291-1
}

Contemporary Political Theory (2022) 21, S34-S37. https://doi.org/10.1057/s41296020-00460-y; published online 2 February 2021

War, Prussian strategist Carl von Clausewitz reminds us, is a clash of wills by which one side attempts to impose its will on the other. War, in other words, is a means to an end, its purpose: victory, since it is only through victory that the ends can be met. Yet the concept of victory is strangely absent from the just war tradition, the moral framework widely used in the west to evaluate the morality of war. In this vitally important contribution to just war thinking, Cian O'Driscoll corrects the record by interrogating the strange absence of victory and articulating a vision of just war that emphasizes its tragedy, contingency, and perhaps most critically of all, impermanence. In so doing, he achieves that rarest of feats: articulating and defending an important addition to a centuries-long tradition of thought. This is a book that demands attention, that should be taken off the shelf and used to inform arguments and debates about the morality of wars and, indeed, of war itself.

Victory is organized as a reflection on why the just war tradition has neglected this essential component of war. Working through seven hypotheses - that the end of just war is peace not victory, that victory is a strategic not normative concept, that just war is more about punishment than war, that victory is associated with conquest, that modern wars are unwinnable, and that victory talk is escalatory O'Driscoll portrays victory as a glitch in the Just War system. It is a ghost in the machine that connects the sometimes prosaic artfulness of moral theorizing with the bloody, tragic, contingent, random, and indeterminate damned awfulness of the battlefield. For the questions raised when we think seriously about what victory means and what is wrought by it reminds us of a sobering adage offered by Ken Booth - the Aberystwyth professor whose students include both O'Driscoll and this reviewer - that 'just war is just war' (p. 12).

Yet the just war tradition was not always so reticent about confronting the awkward questions posed by victory. O'Driscoll begins with a compelling exposition of Augustine to demonstrate that victory was of seminal importance

(C) 2021 The Author(s), under exclusive licence to Springer Nature Limited part of Springer Nature. 14708914 Contemporary Political Theory Vol. 21, S1, S34-S37 www.palgrave.com/journals 
to this first thinker to posit anything remotely like a theory of just war. To summarize O'Driscoll's elegant explanation far too briefly, Augustine maintained that while war was sometimes justified to overturn a grievous ill or protect social order, the goods produced were always imperfect and impermanent. Glorying in slaughter and stimulating false pride, war also established conditions for more sinfulness. Victory in such wars may temporarily extend an imperfect earthly peace or mitigate a heinous injustice, but these things are incomparable to the immutable peace and justice of the city of god and come only at great cost. For Saint Augustine, of course, the tragic necessity of human sinfulness was counteracted by the benign necessity of divine grace. But since few just war thinkers today would accept that eschatology, O'Driscoll explains (p. 35), we are left with an Augustinian account of war that is essentially tragic, an account shorn of the certainty of redemption that was so central to the Bishop of Hippo. Of course, whether we can have one without the other is an open question.

In the hands of modern thinkers, this Augustinian wariness about what might be achieved by war has given rise to the sort of deep skepticism we see in the Christian realism of Reinhold Niebuhr - a skepticism that among Niebuhr's heirs was no doubt fuelled by the recent tendency of some prominent just war thinkers to use the tradition as a vehicle more for justifying war than interrogating it. It may also explain the just war tradition's subsequent awkward neglect of the issue. Yet by mining the tradition, as well as its Greek and Roman antecedents and the reflections of soldiers and strategists from Antoine-Henri Jomini to William Marshal, O'Driscoll recovers a rich vein of thought and debate in which to anchor his own important contribution, one that rewards repeated re-reading.

To illustrate my point, allow me to highlight just three among the dozens of insights that flow from this book's central thesis. One is that associating victory with just war plants in our mind the false idea that victorious wars are just wars. The idea of the providential war - that the decision of the battlefield tells us God's verdict about which side is the more just - is deeply embedded and precedes Christianity. For example, Roman historians and publics typically judged their successful wars to be just, their defeats as signs of immorality. Yet the association of victory with justice runs deep, evident today by the fact that new theories of jus post bellum - justice after war - has much more to say about the responsibilities of victors after a justified war than it does about the duties that fall on the victors of unjust wars (pp. 66-70). Historically speaking, all other things being equal (which of course they never are), the side prepared to fight dirtiest by breaking the rules of just conduct (jus in bello) tends to win. O'Driscoll shakes us from the comfortable delusion that justice and victory are allied and forces us to think more carefully about the duties of the unjust victor, the just vanquished, and, perhaps most painfully of all, about the sometimes necessary trade-offs between fighting well and fighting to win.

(C) 2021 The Author(s), under exclusive licence to Springer Nature Limited part of Springer Nature. 1470- S35 8914 Contemporary Political Theory Vol. 21, S1, S34-S37 
Another insight is that victory conjures up awkward images of violent conquest. In fact, for as long as belief in the idea of providential war persisted - and we know it persisted sufficiently strongly in England that it could propel both aggressive wars and retreats from war as late as the seventeenth century - just war provided a way of justifying and legitimizing such violence. For some, it is possible to draw a more or less straight line between Augustine's justification of religious violence against the Donatists and the Spanish conquistadors' justification for colonization and forced conversion a millennium later. O'Driscoll shows how the protestant jurists Gentili and Grotius tried to accommodate this problem within a lawgoverned society of states by admitting that certain legal rights, including to conquest, could flow from victory in war. He reminds us that no matter how unseemly this may appear, the world today looks the way it does, and has the relatively high degree of order it has, in large part because legal and political recognition have been afforded to the effects of war: Germany moved westwards, Yugoslavia and South Vietnam exterminated, and Eritrea and South Sudan born all of them contemporary legal realities caused by victories (or forced stalemates) in war. Different results in battle would have produced different results in law. In practice, force and law must reach accommodations with one another since neither can permanently triumph over the other. By ignoring that inheritance, the just war tradition removes itself from political realities. By exposing it, though, O'Driscoll opens a crucial avenue for re-connecting them.

An insight raised in the conclusion relates to what O'Driscoll calls 'the art of losing' (p. 145). The just war tradition has nothing to tell us about what to do when we stare defeat in the face. Should the vanquished accept the victor's terms? Should they abide by those terms? Do the answers to those questions depend on the relative justice of their causes and the manner in which they fought? This speaks to one of the most critical strategic issues of our time: the problem of the endless war. In simple terms, the decision of the battlefield is decisive only when the vanquished accept that they have been defeated. If they do not, battles fail as an instrument of decision. With the rise of nationalism and the opportunities to arm and fund themselves that are now afforded to armed groups by global (and informal) trade, even great powers have found it difficult to impose the decision of the battlefield on the weak - though, to return to a point made earlier, governments (such as Sri Lanka, Myanmar, Syria, and Ethiopia) have discovered that victory of sorts in the face of determined resistance is possible by waiving the niceties of jus in bello. The phenomenon of the endless war ruptures the neat distinctions between war and peace upon which the ethics of war depend, and it reminds us that for peace to take hold and endure it is necessary for the vanquished to accept defeat. But when? And how? And at what cost? This book is glorious precisely because it pushes us to confront these difficult questions.

A good book always provokes. Hard-nosed realists might quibble with O'Driscoll's claim that war 'cannot fix our problems for us; the best it can do is

S36 (c) 2021 The Author(s), under exclusive licence to Springer Nature Limited part of Springer Nature. 14708914 Contemporary Political Theory Vol. 21, S1, S34-S37 
defer, contain, or allay them' (p. 13) by pointing out that war has periodically fixed some problems, sometimes permanently so: Rome's destruction of Carthage did resolve the republic's Punic problem. Empiricists might point out that decisive victories tend to produce the longest peace; historians that some states and societies have gained incredible wealth through war and conquest, wealth that continues to this day to mark them out from those they defeated. That O'Driscoll leaves us wiser but also full of questions is a sure sign of what a good book this is, a book that adds a new layer to a centuries-long tradition of thought.

Publisher's Note Springer Nature remains neutral with regard to jurisdictional claims in published maps and institutional affiliations.

Alex J. Bellamy

University of Queensland, Brisbane, QLD 4072, Australia a.bellamy@uq.edu.au 